\title{
ANALISIS PENGARUH VARIABEL-VARIABEL EKONOMI MAKRO TERHADAP RETURN SAHAM
}

\author{
Sunaryo \\ Accounting and Finance Department, Faculty of Economics and Communication, BINUS University \\ Jln. K. H. Syahdan No. 9, Palmerah, Jakarta Barat 11480 \\ sunaryo@binus.ac.id
}

\begin{abstract}
The primary objective of this research is to learn the effecting inflation, interest rate of Indonesian bank certificate, changes of exchange rate, and changes of outstanding money amounts variables with changes of the return Jakarta composite index. Secondary data were collected from Jakarta composite Index, annual Indonesian bank report, Jakarta daily newspaper, and preceding research by using judgment sampling until it got normal distribution data with Kolmogorov-Smirnov test. The results of this research described that inflation, Interest Rate of Indonesian Bank Certificate, and changes of outstanding money variables have not significant effect to the changes of return Jakarta composite index; and changes of exchange rate have significant effect to the changes return of Jakarta composite index. Inflation, interest rate of Indonesian bank certificate, changes of exchange rate, and changes of outstanding money amounts variables have simultaneous significant effect to the changes return of Jakarta composite index. Topic of this research may continue using other countries or added more than $75.20 \%$ of independence variables.
\end{abstract}

Keywords: Infl, IR of IBC, Changes of ER, Changes of OMA Effect to Changes of JCI

\begin{abstract}
ABSTRAK
Tujuan utama penelitian ini adalah untuk memahami pengaruh variabel-variabel inflasi, tarif suku bunga SBI, pertumbuhan nilai tukar, dan pertumbuhan jumlah uang beredar terhadap pertumbuhan return IHSG. Data sekunder dikumpulkan dari Indeks Harga Saham Gabungan, laporan bank Indonesia tahunan, surat kabar harian Jakarta, dan para peneliti sebelumnya dengan menggunakan judgment sampling sampai diperoleh data terdistribusi normal dengan uji kolmogorov smirnov. Hasil penelitian menjelaskan bahwa variabelvariabel inflasi, tarif suku bunga SBI, dan jumlah uang beredar secara signifikan tidak berpengaruh terhadap pertumbuhan return Indeks Harga Saham Gabungan. Selain itu, hasil penelitian juga menunjukkan pertumbuhan nilai tukar secara signifikan berpengaruh terhadap pertumbuhan return Indeks Harga Saham Gabungan. Secara simultan varibel-variabel inflasi, tarif suku bunga sertifikat bank Indonesia, perubahan kurs, dan peruhahan jumlah uang beredar secara signifikan berpengaruh terhadap perubahan return Indeks Harga Saham Gabungan. Penelitian ini dapat dilanjutkan dengan menggunakan negara lain atau menambah lebih dari 75,20\% variabel bebas baru.
\end{abstract}

Kata kunci: Infl, IR of IBC, Changes of ER. Changes of OMA Effect to Changes of JCI 


\section{PENDAHULUAN}

Lingkungan ekonomi makro merupakan salah satu lingkungan yang memengaruhi operasional rutin sehari-hari perusahaan. Para investor harus memerhatikan beberapa indikator ekonomi makro yang dapat memengaruhi kegiatan operasonal rutin perusahaan. Kemampuan investor dalam memahami kondisi ekonomi makro sangat berguna untuk pengambilan keputusan investasi dalam rangka memperkecil risiko investasi. Beberapa peneliti sebelumnya telah melakukan pengamatan terhadap variabel ekonomi makro antara lain inflasi, suku bunga SBI, kurs, dan jumlah uang yang beredar pengaruhnya terhadap return saham dengan berbagai hasil pro dan kontra. Gazioglu dan Bulut (2004) pada hasil penelitian di Istambul Stock Exchange (ISE) menemukan bahwa variabel inflasi secara signifikan memengaruhi return saham. Berbeda dengan hasil penelitian yang dilakukan oleh Gunsel dan Cukur (2007) pada UK Stock Exchage dan Buyuksalvarci (2010), mereka menemukan bahwa variabel inflasi secara signifikan tidak memengaruhi return saham. Hadi dan Asmi (2005), Kandir (2008), Ahmad, Rehman, dan Raoof (2010) pada hasil penelitian menemukan bahwa variabel suku bunga secara signifikan memengaruhi return saham. Berbeda dengan hasil penelitian Mok (1993), Karamustafa dan Kucukkale (2004) yang menyatakan bahwa variabel suku bunga secara signifikan tidak memengaruhi return saham. Hadi dan Asmi (2005), Kandir (2008), Ahmad, Rehman, dan Raoof (2010) pada penelitiannya menemukan bahwa variabel kurs secara signifikan memengaruhi return saham. Ini berbeda dengan hasil penelitian Mok (1993), Karamustafa dan Kucukkade (2004), dan Buyuksalvarci (2010) yang pada hasil penelitiannya menemukan bahwa variabel kurs secara signifikan tidak memengaruhi return saham. Buyuksalvarci (2010) lewat hasil penelitiannya menemukan bahwa variabel jumlah uang yang beredar secara signifikan memengaruhi return saham, berbeda dengan hasil penelitian Rahman dan Mustafa (2010) yang menyatakan bahwa jumlah uang yang beredar secara signifikan tidak memengaruhi return saham. Bursa Efek Indonesia memiliki IHSG (Indeks Harga Saham Gabungan) yang menjelaskan pergerakan harga saham biasa dan saham istimewa yang tercatata di BEI. Dari hasil penelitian para peneliti sebelumnya, variabel-variabel makro bersifat independen seperti inflasi, suku bunga SBI, kurs, dan jumlah uang yang beredar menyatakan bahwa secara signifikan ada yang berpengaruh terhadap return saham dan ada pula yang tidak berpengaruh terhadap return saham.

\section{Tinjauan Pustaka}

Menurut Siamat (2004:268) saham adalah surat bukti atau tanda kepemilikan bagian modal pada suatu perseroan terbatas. Berdasarkan Hartono (2003:67) saham dibagi menjadi 2 jenis yaitu saham biasa dan saham istimewa. Saham biasa merupakan instrumen ekuitas yang memiliki hak sisa atas kekayaan setelah hak-hak instrumen ekuitas lainnya, sedangkan saham istimewa merupakan saham yang mempunyai sifat gabungan antara saham biasa dan obligasi. Menurut Jones (2002:128) "share return is a percentage measure relating all cash flow on a security for a given period to its purchase price". Return saham dibedakan menjadi dua jenis, yaitu realized return (return realisasi) dan expected return (return yang diharapkan). Realized return merupakan return yang telah terjadi dan dihitung berdasarkan data historis dan dapat digunakan sebagai salah satu alat pengukur kinerja perusahaan serta sebagai dasar penentuan expected return. Expected return adalah return yang diharapkan akan diperoleh investor masa yang akan datang. Menurut Hartono (2003:110) return saham merupakan keseluruhan dari capital gain (loss) dan yield. Capital gain (loss) merupakan selisih antara harga jual saham dengan beli saham, sedangkan yield merupakan hasil atau pendapatan yang diperoleh dari investasi saham berupa dividen.

$$
\text { Return saham (Rit) }=\text { Pit }-\operatorname{Pit}(\mathrm{t}-1) / \operatorname{Pit}(\mathrm{t}-1)
$$

Rit = return saham pada hari/periode $\mathrm{t}$

Pit = harga penutupan saham pada hari periode $\mathrm{t}$

Pit ( $\mathrm{t}-1)$ = harga penutupan saham sebelum hari/periode $\mathrm{t}$ 
Menurut Case and Fair (1999:216) "inflation is an increase in the overall price level". Sedangkan menurut Rahardja dan Manurung (2004:155) inflasi adalah gejala kenaikan harga barangbarang bersifat umum dan terus-menerus. Menurut Sukirno (2004:15) faktor-faktor penyebab inflasi, seperti kenaikan harga barang-barang yang diimpor, penambahan jumlah uang yang berlebihan tanpa diikuti penambahan produksi dan penawaran barang, dan terjadinya kekacauan politik dan ekonomi akibat pemerintahan yang kurang bertanggung jawab. Menurut Boediono (1990:167) ada 3(tiga) teori inflasi seperti: teori kuantitas, teori Keynes, dan teori strukturalis. Teori kuantitas menyoroti peranan dalam proses inflasi seperti jumlah uang yang beredar. Maksudnya, jika ada penambahan volume uang yang beredar, cenderung akan terjadi inflasi, serta ekspektasi masyarakat, maksudnya laju inflasi ditentukan oleh penambahan jumlah uang beredar dan harapan masyarakat mengenai kenaikan hargaharga barang pada masa mendatang. Teori Keynes menjelaskan bahwa inflasi terjadi karena kelompok masyarakat ingin hidup di luar batas kemampuan ekonominya. Maksudnya, bila jumlah permintaan efektif dari semua golongan masyarakat pada tingkat harga barang yang berlaku melebihi jumlah maksimum barang-barang yang dihasilkan masyarakat, terjadi inflationary gap. Inflationary gap timbul karena golongan masyarakat tersebut berhasil menerjemahkan aspirasinya menjadi permintaan yang efektif atas barang-barang. Sedangkan teori Strukturalitas menekankan pada rigidities (ketegaran) dari struktur perekonomian negara-negara sedang berkembang, teori ini mengaitkan faktor-faktor struktural perekomian yang dalam jangka panjang bisa berubah secara bertahap. Hasil penelitian Gazioglu dan Bulut (2004) pada Istambul stock exchange (ISE) menemukan bahwa secara signifikan inflasi berpengaruh terhadap return saham. Ini berbeda dengan hasil penelitian Hadi dan Asmi (2005) pada kelompok perusahaan sektor perdagangan yang terdaftar di Bursa Efek Jakarta menemukan bahwa secara signifikan inflasi tidak berpengaruh terhadap return saham, sama dengan hasil penelitian Gunsel dan Cukur (2007) dan Buyuksalvarci (2010) juga menyatakan secara signifikan inflasi tidak berpengaruh terhadap return saham karena para investor kemungkinan melakukan pengalihan dana dari modal ke aktiva riil.

Sertifikat Bank Indonesia (SBI) adalah surat berharga yang dikeluarkan oleh Bank Indonesia sebagai pengakuan utang berjangka waktu pendek (1-3 bulan) dengan sistem diskonto. SBI merupakan salah satu mekanisme yang digunakan bank Indonesia untuk mengontrol kestabilan nilai rupiah. Dengan menjual SBI Bank Indonesia dapat menyerap kelebihan jumlah uang primer yang beredar. BI rate merupakan tarif suku bunga kebijakan yang mencerminkan kebijakan moneter yang ditetapkan Bank Indonesia dan diumumkan secara luas kepada masyarakat. Penetapan suku bunga SBI menjadi salah satu kebijakan moneter yang biasa dijalankan pemerintah untuk menstabilkan nilai tukar rupiah. Kenaikan dan penurunan tigkat suku bunga SBI berdampak pada tingkat bunga secara umum. Investor selaku pemilik modal menanggapi beragam atas kenaikan dan penurunan tarif suku bunga SBI. Ada investor berpendapat bahwa kenaikan tarif suku bunga SBI menyebabkan para pengusaha di sektor riil akan mengalihkan sumber pembiayaan dari sektor perbankan ke sektor publik. Ada pula investor beranggapan bahwa jika terjadi kenaikan dan penurunan tarif suku bunga SBI memilih menanamkan uangnya pada aktiva keuangan misalnya menjual sahamnya untuk membeli aktiva keuangan seperti deposito. Hasil penelitian Hadi dan Asmi (2005) dan Ahmad, Rehman, Raoof(2010) menemukan bahwa secara signifikan suku bunga SBI berpengaruh terhadap return saham, berbeda dengan hasil peneltian Buyuksalvarci (2010) yang menyatakan bahwa secara signifikan suku bunga tidak berpengaruh terhadap return saham. Sukirno (2004:397) menyatakan bahwa kurs didefinisikan sebagai perbandingan nilai tukar mata uang suatu negara terhadap nilai tukar mata uang negara lain. Hasil penelitian Hadi dan Asmi (2005), Kandir (2008), dan Ahmad, Rehman, dan Raoof(2010) menyatakan bahwa secara signifikan kurs berpengaruh terhadap return saham, yang berbeda dengan hasil penelitian Mok (1993), Karamustafa dan Kucukale (2004), serta Buyuksalvarci (2010) yang menyatakan bahwa secara signifikan kurs tidak berpengaruh terhadap return saham.

Menurut Boediono (1982:86), jumlah uang beredar adalah keseluruhan uang kartal dan uang giral yang tersedia digunakan masyarakat. Uang kartal adalah uang tunai yang dikeluarkan pemerintah atau bank sentral yang secara langsung di bawah kekuasaan masyarakat umum untuk digunakan. Sedangkan uang giral adalah keseluruhan jumlah nilai saldo rekening Koran (giro) yang dimiliki 
masyarakat pada bank-bank umum. Jadi jumlah uang beredar pada suatu saat merupakan penjumlahan dari uang kartal dan uang giral. Suparmoko (1994:100) menyatakan bahwa jumlah uang beredar adalah semua uang kartal dan uang giral yang ada di tangan masyarakat, atau jumlah uang kartal dan uang giral di luar sistem moneter yang dimiliki sektor swasta domistik. Perhitungan jumlah uang yang beredar umumnya menggunakan notasi M0, M1, M2, dan M3. M0 merupakan jumlah semua fisik mata uang ditambah rekening di bank sentral yang dapat ditukar dengan mata yang fisik. M1 merupakan jumlah uang beredar secara sempit meliputi uang kartal dan deposito yang dapat digunakan sebagai alat tukar. M2 merupakan M1 ditambah dengan tabungan dan segala jenis deposito berjangka berdenominasi kecil termasuk rekening pasar uang dan pinjaman antar bank umum. M3 merupakan M2 ditambah semua unsur lainnya seperti deposito berjangka dalam jumlah besar dan saldo reksa dana di pasar institusi. Buyuksalvarci (2010) menyatakan bahwa formulasi pertumbuhan jumlah uang yang beredar adalah:

$$
\mathrm{G}(\mathrm{Vi}) \mathrm{t}=\mathrm{Ln}(\mathrm{Vi}) \mathrm{t}-\mathrm{Ln}(\mathrm{Vi}) \mathrm{t}-1
$$

$\mathrm{G}(\mathrm{Vi}) \mathrm{t}=$ Pertumbuhan jumlah uang beredar,

(Vi)t = Jumlah uang beredar pada bulan $\mathrm{t}$,

(Vi)t-1 = Jumlah uang beredar sebelum bulan $\mathrm{t}$

Hasil penelitian Buyuksalvarci (2010) menyatakan bahwa secara signifikan jumlah uang beredar berpengaruh terhadap return saham, jumlah uang beredar dengan pertumbuhan wajar memberikan pengaruh positif terhadap ekonomi dan pasar ekuitas jangka pendek dan pada akhirnya memengaruhi return saham. Hal itu berbeda dengan hasil penelitian Rahman dan Mustafa (2008) yang menyatakan bahwa jumlah uang beredar secara signifikan tidak berpengaruh terhadap return saham.

Hasil penelitian para peneliti tersebut dapat memotivasi untuk melakukan penelitian kembali untuk menguji jika variabel makro independen seperti inflasi, suku bunga SBI, dan jumlah uang beredar secara signifikan berpengaruh terhadap return saham. Hasil penelitian sebelumnya ada yang menjelaskan secara signifikan berpengaruh terhadap return saham dan ada pula secara signifikan tidak berpengaruh terhadap return saham.

\section{METODE PENELITIAN}

Penelitian ini menggunakan data sekuder berupa Indeks Harga Saham Gabungan (IHSG) yang dikenal dengan nama Jakarta Composite Index (JKSE) yang ada di Bursa Efek Indonesia (BEI), laporan tahunan Bank Indonesia, dan surat kabar harian di Jakarta dari 2006 sampai dengan 2010 dengan sampel bulanan, serta hasil penelitian ilmiah dari para peneliti sebelumnya. Sampel yang digunakan adalah judment sampling dengan cara memilih sampel sampai terbentuk distribusi normal. Uji distribusi normal yang digunakan adalah Kolmogorov Smirnov dengan signikansi 0,05. Jika hasil signifikansi lebih besar dari 0,05 (signifikan), berarti data terdistribusi secara normal. Jika hasil signikansi lebih kecil dari 0,05 (tidak signifikan), berarti data tidak terdistribusi secara normal.

Variabel bebas adalah Inflasi, Suku bunga SBI, Kurs (Pertumbuhan kurs), dan Jumlah uang yang beredar (Pertumbuhan jumlah uang yang beredar). Sedangkan variabel terikat adalah Return saham (Pertumbuhan return saham). Variabel-variabel ini dipilih karena terdapat perbedaan hasil penelitian dari para peneliti sebelumnya. Hasil penelitian sebelumnya ada yang menjelaskan bahwa variabel bebas seperti inflasi, suku bunga SBI, kurs, dan jumlah uang yang beredar secara signifikan berpengaruh terhadap return saham. Ada pula yang menjelaskan secara signifikan tidak berpengaruh terhadap return saham. Uji hipotesis yang digunakan adalah uji $\mathrm{F}$ (simultan) dengan regresi sederhana $(\mathrm{Y}=\mathrm{a}+\mathrm{b} 1 \mathrm{X} 1+\mathrm{b} 2 \mathrm{X} 2+\mathrm{b} 3 \mathrm{X} 3+\mathrm{b} 4 \mathrm{X} 4+\mathrm{e})$ karena variabel terikatnya (return saham bukan damy), dengan 
X1 adalah inflasi, X2 suku bunga, X3 pertumbuhan kurs, dan X4 pertumbuhan jumlah uang beredar. Uji t (parsial) dengan model hipotesis penelitian adalah sebagai berikut:

Ha1: Secara bersama-sama terdapat pengaruh signifikan antara inflasi, suku bunga SBI, kurs (pertumbuhan kurs), dan jumlah uang yang beredar (pertubuhan jumlah uang yang beredar) terhadap return saham.

Ho1: Secara bersama-sama tidak terdapat pengaruh signifikan antara inflasi, suku bunga SBI, kurs (pertumbuhan kurs), dan jumlah uang yang beredar (pertumbuhan jumlah uang yang beredar) terhadap return saham.

Jika hasil signifikansi lebih kecil dari 0,05, signifikan; dan jika lebih besar dari 0,05, tidak signifkan.

Ha2: Terdapat pengaruh signifikan antara inflasi dengan pertumbuhan return saham.

Ho2: Tidak terdapat pengaruh signifikan antara inflasi dengan pertumbuhan return saham.

Ha3: Terdapat pengaruh signifikan antara suku bunga SBI dengan pertumbuhan return saham.

Ho3: Tidak terdapat pengaruh signifikan antara suku bunga SBI dengan pertumbuhan return saham.

Ha4: Terdapat pengaruh signifikan antara kurs (pertumbuhan kurs) dengan pertumbuhan return saham.

Ho4: Tidak terdapat pengaruh signifikan antara kurs (pertumbuhan kurs) dengan pertumbuhan return saham.

Ha5: Terdapat pengaruh signifikan antara jumlah uang yang beredar (pertumbuhan jumlah uang yang beredar) terhadap pertumbuhan return saham.

Ho5: Tidak terdapat pengaruh signifikan antara jumlah uang yang beredar (pertumbuhan jumlah uang beredar) terhadap pertumbuhan return saham.

Jika hasil signifikansi lebih kecil dari 0,05, signifikan; dan jika lebih besar dari 0,05, tidak signifkan.

\section{HASIL DAN PEMBAHASAN}

Data pada tabel 1 menunjukkan bahwa semua variabel bebas seperti inflasi, suku bunga SBI, kurs (pertumbuhan kurs), jumlah uang yang beredar (pertumbuhan jumlah uang beredar), dan pertumbuhan return ISHG terdistribusi secara normal karena Asymp. Sig. lebih besar dari 0,05, yaitu: 0,103 untuk variabel inflasi, 0,165 untuk variabel suku bunga SBI, 0,127 untuk variabel kurs (pertumbuhan kurs), 0,924 untuk variabel jumlah uang yang beredar (pertumbuhan jumlah uang beredar), dan 0,531 untuk variabel return saham (pertumbuhan return IHSG).

Tabel 1 Kolmogorov-Smirnov Test

\begin{tabular}{lrrrrr} 
& Inflasi & $\begin{array}{c}\text { Suku Bunga } \\
\text { SBI }\end{array}$ & $\begin{array}{c}\text { Pertumbuhan } \\
\text { Kurs }\end{array}$ & $\begin{array}{c}\text { Pertumbuhan } \\
\text { Uang Beredar }\end{array}$ & $\begin{array}{r}\text { Pertumbuhan } \\
\text { Return IHSG }\end{array}$ \\
\hline $\mathrm{N}$ & 60 & 60 & 60 & 60 & 80 \\
Normal Mean & .090683 & .090877 & .000960 & .012114 & .000535 \\
Deviation Standard & .043472 & .018737 & .036813 & .016509 & .004470 \\
Most Extreme & .157 & .144 & .152 & .071 & .104 \\
Differences : & & & & & .071 \\
-Positive & .157 & .144 & .152 & -.050 & .102 \\
-Negative & -.096 & -.104 & -.114 & .549 & .104 \\
Kolmogorov Smirnov & 1.219 & 1.117 & 1.175 & .924 & .808 \\
Asymp. Sig (2-tailed) & .103 & .165 & .127 & .531 \\
\hline
\end{tabular}


Data pada tabel 2 menunjukkan bahwa adjusted R sebesar 0,547. Artinya, variabel bebas seperti inflasi, suku bunga SBI, pertumbuhan kurs, dan pertumbuhan jumlah uang yang beredar mempunyai korelasi positif terhadap pertumbuhan return saham sebesar 0,547. Sedangkan adjusted $\mathrm{R}$ Square sebesar 0,248. Artinya, variabel bebas seperti inflasi, suku bunga SBI, pertumbuhan kurs, dan pertumbuhan jumlah uang yang beredar berpengaruh terhadap pertumbuhan return saham hanya sebesar $24,80 \%$. Sedangkan $75,20 \%$ dipengaruhi variabel bebas lain yang tidak diteliti dalam penelitian ini.

Tabel 2 Model Summary

\begin{tabular}{cccccc} 
Model & R & R. Square & $\begin{array}{c}\text { Adjusted R } \\
\text { Square }\end{array}$ & $\begin{array}{c}\text { Std. Error of } \\
\text { The Estimate }\end{array}$ & $\begin{array}{c}\text { Durbin- } \\
\text { Watson }\end{array}$ \\
\hline 1 & $.547^{\mathrm{a}}$ & .299 & .248 & .0038759 & 1.904 \\
\hline
\end{tabular}

a. Predictors: inflasi, suku bunga SBI, Pertumbuhan kurs, Pertumbuhan jumlah uang beredar.

b. Dependent Variable: Pertumbuhan return IHSG.

Berdasarkan data pada tabel 3, uji F mempunyai nilai signifikansi sebesar 0,001 lebih kecil dari 0,05. Artinya, Ha1 diterima dan Ho1 ditolak atau signifikan; berarti model regresi untuk variabel bebas (inflasi, suku bunga SBI, dan pertumbuhan kurs) berpengaruh secara signifikan terhadap variabel terikat (pertumbuhan return saham) dengan tingkat keyakinan sebesar 95\%. Dengan kata lain, model regresi adalah fit (layak).

Tabel 3 Anova ${ }^{\mathrm{b}}$ (Uji F)

\begin{tabular}{llccccc}
\hline & Model & $\begin{array}{c}\text { Sum of } \\
\text { Square }\end{array}$ & df & $\begin{array}{c}\text { Mean of } \\
\text { Square }\end{array}$ & F & Sig. \\
\hline 1 & Regression & .000 & 4 & .000 & 5.866 & $.001^{\mathrm{a}}$ \\
& Residual & .001 & 55 & .000 & & \\
\hline & Total & .001 & 59 & & & \\
\hline
\end{tabular}

a. Predictors: (Constants), Inflasi, Suku bunga SBI, Pertumbuhan kurs, Pertumbuhan uang beredar.

b. Dependent Variable : Return IHSG

Tabel 4 (uji t) menunjukkan bahwa signifikansi inflasi sebesar 0,143 lebih besar dari 0,05. Dengan demikian, Ha2 ditolak atau Ho2 diterima, berarti variabel inflasi secara signifikan tidak berpengaruh terhadap pertumbuhan return saham. Signifikansi suku bunga sebesar 0,253 lebih besar dari 0,05. Dengan demikian, Ha3 ditolak atau Ho3 diterima, berarti variabel suku bunga SBI secara signifikan tidak berpengaruh terhadap pertumbuhan return saham. Signifikansi pertumbuhan kurs sebesar 0,000 lebih kecil dari 0,05. Dengan demikian, Ha4 diterima atau Ho4 ditolak, berarti variabel pertumbuhan kurs secara signifikan berpengaruh terhadap pertumbuhan return saham. Signifikansi pertumbuhan jumlah uang beredar sebesar 0,353 lebih besar dari 0,05. Dengan demikian, Ha5 ditolak atau Ho5 diterima, berarti variabel pertumbuhan jumlah uang beredar secara signifikan tidak berpengaruh terhadap pertumbuhan return saham. Adapun persamaan regresinya adalah:

$$
\mathrm{Y}=-0,002-0,034 \mathrm{X} 1+0,062 \mathrm{X} 2-0,058 \mathrm{X} 3-0,029 \mathrm{X} 4+\mathrm{e}
$$


Tabel 4 Coefficient Regressions ${ }^{\mathrm{a}}(\mathrm{Uji}$ t)

\begin{tabular}{|c|c|c|c|c|c|c|c|}
\hline \multirow[t]{2}{*}{ Model } & \multicolumn{2}{|c|}{$\begin{array}{l}\text { Unstdardized } \\
\text { Coefficients }\end{array}$} & \multirow{2}{*}{$\begin{array}{l}\text { Std. } \\
\text { Coeff } \\
\text { Beta }\end{array}$} & \multirow[t]{2}{*}{$\mathbf{t}$} & \multirow[t]{2}{*}{ Sig. } & \multicolumn{2}{|c|}{$\begin{array}{c}\text { Collinearity } \\
\text { Statistics }\end{array}$} \\
\hline & B & Std Error & & & & Tolerance & VIF \\
\hline (Constant) & -.002 & .003 & & - & .636 & & \\
\hline Inflasi & -.034 & .023 & -.335 & .4750 & .143 & .251 & 3.985 \\
\hline Suku Bunga SBI & .062 & .054 & .260 & - & .253 & .252 & 3.967 \\
\hline Pertumbuhan Kurs & -.058 & .014 & -.478 & .1487 & .000 & .947 & 1.055 \\
\hline Pertumbuhan Uang Beredar & -.029 & .031 & -.109 & $\begin{array}{c}1.155 \\
- \\
4.121 \\
-.936\end{array}$ & .353 & .945 & 1.058 \\
\hline
\end{tabular}

a. Dependent Variable : Return IHSG

\section{SIMPULAN}

Sampling data dilakukan secara judgment sampling dan terdistribusi secara normal serta memenuhi syarat regresi. Hasil penelitian ini menjelaskan bahwa variabel inflasi secara signifikan tidak berpengaruh terhadap return saham. Hasil ini sama dengan hasil penelitian Hadi dan Asmi (2005), Gunsel dan Cukur (2007), serta Buyuksalvarci (2010) juga menjelaskan bahwa variabel inflasi secara signifikan tidak berpengaruh terhadap return saham. Akan tetapi, hasil penelitian ini berbeda dengan hasil penelitian Gazioglu dan Cukur (2004) yang menjelaskan bahwa variabel inflasi secara signifikan berpengaruh terhadap retun saham. Variabel suku bunga secara signifikan tidak berpengaruh terhadap return saham sama dengan hasil penelitian Buyuksalvarci (2010), berbeda dengan hasil penelitian Hadi dan Asmi (2005) serta Ahmad, Rehman, Raoof (2010) yang menjelaskan bahwa variabel suku bunga secara signifikan berpengaruh terhadap return saham. Variabel pertumbuhan kurs secara signifikan berpengaruh terhadap return saham, berbeda dengan hasil penelitian Mok (1993), Karamustafa dan Kucukale (2004), serta Buyuksalvarci (2010) yang menjelaskan bahwa variabel perubahan kurs secara signifikan tidak berpengaruh terhadap return saham. Variabel pertumbuhan jumlah uang beredar secara signifikan tidak berpengaruh terhadap return saham, sama dengan hasil penelitian Rehman dan Mustafa (2008), namun berbeda dengan hasil penelitian Buyuksalvarci (2010) yang menjelaskan bahwa varibel pertumbuhan jumlah uang beredar secara signifikan berpengaruh terhadap return saham.

Penelitian dapat dilanjutkan dengan menambah variabel bebas lain yang belum diteliti dalam penelitian ini. Variabel bebas lainnya diperkirakan sebesar 75,20\%. Penelitian lanjutan dapat menggunakan objek penelitian negara selain Hongkong, Pakistan, Turki, Inggris, dan Indonesia.

\section{DAFTAR PUSTAKA}

Ahmad, Rehman, Raoof (2010). Do Interest Rate, Exchange Rate Effect Stock Return? A Pakistani perspective. International Research Journal Of Finance and Economics. (50), page 146-150.

Boediono. (1990). Seri Synopsis Pengantar Ilmu Ekonomi-Ekonomi Makro. Edisi ketiga. Yogyakarta: BPFE.

Buyuksalvarci, A. (2010). The Effect of Macro Economics Variables on Stock Return. Evidence from Turkey. European Journal of Social Sciences. (14), page 404-415. 
Case, K. E., and Fair, R. C. (1999). Principles of Macro Economics. New Jersey: Prentice Hall.

Gazioglu, S., and Bulut. (2004). Nominal Stock Returns and Inflation: Evidence from the Istambul Stock Exchange. Economic Working Paper at WUSTI.

Gunsel and Cukur (2007). The Effect of Macro Economics Factors on The London Stock Return. A Sectoral Approach. International Research Journal of Finance And Eeconomics. (10). Page $142-150$.

Hartono, Y. (2003). Teori Portofolio dan Analisis Investasi. Edisi ketiga. Yogyakarta: BPFE.

Jones, C. P (2002). Investment Analysis and Management. $8^{\text {th }}$ Edition. New York: John Wiley and Son.

Kandir, S. Y. (2008). Macro Economic Variables, Firm Characteristics and Stock Returns. Evidence from Turkey. International Research Journal of Finance and Economics. (16) Page 35-45.

Mok, H. M. K. (1993). Causality of Interest Rate, Exchange Rate, and Stock Prices at Stock Market Open and Close In Hongkong. Asia Pacific Journal of Management (10). 123-143.

Rahardja, P dan Manurung, M (2004). Teori Ekonomi Makro. Edisi Kedua. Jakarta: Fakultas Ekonomi Universitas Indonesia.

Rahman, M., and Mustafa. (2010). Influence of Money Supply and Oil Price on U.S. Stock Market. North American Journal of Finance and Banking Research. (2) page 1-12.

Siamat, D. (2004). Manajemen Lembaga Keuangan. Jakarta: Fakultas Ekonomi Universitas Indonesia.

Sukirno, S. (2004). Ekonomi Makro-Teori Pengantar. Jakarta: Raja Grafindo Persada.

Suparmoko, M. (1994). Pengantar Ekonomi Makro. Yogyakarta: BPFE. 


\section{LAMPIRAN}

\begin{tabular}{|c|c|c|c|c|c|c|}
\hline No & $\begin{array}{c}\text { Bulan dan } \\
\text { Tahun }\end{array}$ & Inflasi & $\begin{array}{c}\text { Suku Bunga } \\
\text { SBI }\end{array}$ & $\begin{array}{c}\text { Pertumbuhan } \\
\text { Kurs }\end{array}$ & $\begin{array}{l}\text { Pertumbuhan } \\
\text { Uang Beredar }\end{array}$ & $\begin{array}{l}\text { Pertumbuhan } \\
\text { Return IHSG }\end{array}$ \\
\hline 01 & Januari 2006 & $7,32 \%$ & $7,42 \%$ & $-0,0021$ & $-0,0172$ & 0,0176 \\
\hline 02 & Pebruari 2006 & $7,15 \%$ & $7,43 \%$ & 0,0043 & $-0,0037$ & 0,0015 \\
\hline 03 & Maret 2006 & $8,81 \%$ & $7,44 \%$ & 0,0136 & 0,0084 & $-0,0005$ \\
\hline 04 & April 2006 & $8,12 \%$ & $7,77 \%$ & 0,0180 & 0,0228 & $-0,0032$ \\
\hline 05 & Mei 2006 & $7,40 \%$ & $7,95 \%$ & $-0,0063$ & 0,0019 & 0,0031 \\
\hline 06 & Juni 2006 & $7,42 \%$ & $8,25 \%$ & 0,0145 & 0,0260 & 0,0017 \\
\hline 07 & Juli 2006 & $7,84 \%$ & $8,49 \%$ & 0,0190 & 0,0135 & 0,0019 \\
\hline 08 & Agustus 2006 & $8,33 \%$ & $9,51 \%$ & 0,0191 & 0,0250 & $-0,0049$ \\
\hline 09 & September 2006 & $9,06 \%$ & $10,00 \%$ & 0,0246 & 0,0305 & 0,0020 \\
\hline 10 & Oktober 2006 & $17,89 \%$ & $11,00 \%$ & $-0,0136$ & 0,0132 & $-0,0008$ \\
\hline 11 & Nopember 2006 & $18,38 \%$ & $12,25 \%$ & $-0,0053$ & 0,0022 & 0,0019 \\
\hline 12 & Desember 2006 & $17,11 \%$ & $12,75 \%$ & -0.0182 & 0,0295 & 0,0031 \\
\hline 13 & Januari 2007 & $17,03 \%$ & $12,75 \%$ & $-0,0369$ & $-0,0103$ & 0,0028 \\
\hline 14 & Pebruari 2007 & $17,92 \%$ & $12,75 \%$ & $-0,0253$ & 0,0025 & $-0,0004$ \\
\hline 15 & Maret 2007 & $15,74 \%$ & $12,75 \%$ & $-0,0089$ & 0,0010 & 0,0033 \\
\hline 16 & April 2007 & $15,40 \%$ & $12,75 \%$ & $-0,0256$ & 0,0025 & 0,0061 \\
\hline 17 & Mei 2007 & $15,60 \%$ & $12,50 \%$ & 0,0054 & 0,0324 & $-0,0049$ \\
\hline 18 & Juni 2007 & $15,53 \%$ & $12,50 \%$ & 0,0421 & 0,0130 & $-0,0002$ \\
\hline 19 & Juli 2007 & $15,15 \%$ & $12,25 \%$ & $-0,0253$ & $-0,0044$ & 0,0009 \\
\hline 20 & Agustus 2007 & $14,90 \%$ & $11,75 \%$ & $-0,0034$ & 0,0176 & $-0,0022$ \\
\hline 21 & September 2007 & $14,55 \%$ & $11,25 \%$ & 0,0054 & 0,0164 & 0,0031 \\
\hline 22 & Oktober 2007 & $6,29 \%$ & $10,75 \%$ & 0,0048 & 0,0262 & 0,0022 \\
\hline 23 & Nopember 2007 & $5,27 \%$ & $10,25 \%$ & $-0,0058$ & 0,0097 & 0,0038 \\
\hline 24 & Desember 2007 & $6,60 \%$ & $9,75 \%$ & $-0,0053$ & 0,0320 & 0,0023 \\
\hline 25 & Januari 2008 & $6,26 \%$ & $9,50 \%$ & 0,0004 & $-0,0132$ & $-0,0020$ \\
\hline 26 & Pebruari 2008 & $6,30 \%$ & $9,25 \%$ & 0,0077 & 0,0021 & $-0,0009$ \\
\hline 27 & Maret 2008 & $6,52 \%$ & $9,00 \%$ & $-0,0046$ & 0,0067 & 0,0021 \\
\hline 28 & April 2008 & $6,29 \%$ & $9,00 \%$ & $-0,0038$ & 0,0055 & 0,0042 \\
\hline 29 & Mei 2008 & $66,01 \%$ & $8,75 \%$ & $-0,0281$ & 0,0069 & 0,0021 \\
\hline 30 & Juni 2008 & $5,77 \%$ & $8,50 \%$ & 0,0256 & 0,0414 & 0,0007 \\
\hline 31 & Juli 2008 & $6,06 \%$ & $8,25 \%$ & 0,0146 & 0,0143 & $-0,0037$ \\
\hline 32 & Agustus 2008 & $6,51 \%$ & $8,25 \%$ & 0,0244 & 0.0099 & $-0,0009$ \\
\hline 33 & September 2008 & $6,95 \%$ & $8,25 \%$ & -0.0290 & 0,0168 & 0,0034 \\
\hline 34 & Oktober 2008 & $6,88 \%$ & $8,25 \%$ & $-0,0037$ & 0,0114 & 0,0053 \\
\hline 35 & Nopember 2008 & $6,71 \%$ & $8,25 \%$ & 0,0300 & 0,0169 & $-0,0002$ \\
\hline 36 & Desember 2008 & $6,59 \%$ & $8,00 \%$ & 0,0046 & 0,0544 & 0,0005 \\
\hline 37 & Januari 2009 & $7,36 \%$ & $8,00 \%$ & $-0,0136$ & $-0,0336$ & $-0,0015$ \\
\hline 38 & Pebruari 2009 & $7,40 \%$ & $8,00 \%$ & $-0,0258$ & 0,0045 & 0,0016 \\
\hline 39 & Maret 2009 & $8,17 \%$ & $8,00 \%$ & 0,0183 & $-0,0058$ & $-0,0045$ \\
\hline 40 & April 2009 & $8,96 \%$ & $8,00 \%$ & 0,0018 & 0,0138 & $-0,0016$ \\
\hline 41 & Mei 2009 & $10,38 \%$ & $8,25 \%$ & 0,0091 & 0,0170 & 0,0023 \\
\hline 42 & Juni 2009 & $11,03 \%$ & $8,50 \%$ & $-0,0100$ & 0,0378 & $-0,0016$ \\
\hline 43 & Juli 2009 & $11,90 \%$ & $8,75 \%$ & $-0,0116$ & $-0,0121$ & $-0,0014$ \\
\hline 44 & Agustus 2009 & $11,85 \%$ & $9,00 \%$ & 0,0038 & $-0,0021$ & $-0,0019$ \\
\hline 45 & September 2009 & $12,14 \%$ & $9,25 \%$ & 0,0246 & 0,0539 & $-0,0080$ \\
\hline 46 & Oktober 2009 & $11,77 \%$ & $9,50 \%$ & 0,1724 & 0,0194 & $-0,0147$ \\
\hline 47 & Nopember 2009 & $11,68 \%$ & $9,50 \%$ & 0,1051 & 0,0210 & $-0,0042$ \\
\hline 48 & Desember 2009 & $11,06 \%$ & $9,25 \%$ & $-0,0988$ & 0,0229 & 0,0061 \\
\hline 49 & Januari 2010 & $9,17 \%$ & $8,75 \%$ & 0,0370 & $-0,0052$ & $-0,0041$ \\
\hline 50 & Pebruari 2010 & $8,60 \%$ & $8,25 \%$ & 0,0550 & 0,0138 & $-0,0010$ \\
\hline 51 & Maret 2010 & $7,92 \%$ & $7,75 \%$ & $-0,0338$ & 0,0087 & 0,0071 \\
\hline 52 & April 2010 & $7,31 \%$ & $7,50 \%$ & $-0,0745$ & $-0,0022$ & $-0,0084$ \\
\hline
\end{tabular}




\begin{tabular}{llllrrr}
\hline 53 & Mei 2010 & $6,04 \%$ & $7,25 \%$ & $-0,0348$ & 0,0075 & 0,0056 \\
54 & Juni 2010 & $3,65 \%$ & $7,00 \%$ & $-0,0111$ & 0,0258 & 0,0008 \\
55 & Juli 2010 & $2,71 \%$ & $6,75 \%$ & $-0,0298$ & $-0,0084$ & 0,0061 \\
56 & Agustus 2010 & $2,75 \%$ & $6,50 \%$ & 0,0141 & 0,0174 & 0,0002 \\
57 & September 2010 & $2,83 \%$ & $6,50 \%$ & $-0,0377$ & 0,0116 & 0,0035 \\
58 & Oktober 2010 & $2,57 \%$ & $6,50 \%$ & $-0,0140$ & 0,0015 & $-0,0021$ \\
59 & Nopember 2010 & $2,41 \%$ & $6,50 \%$ & $-0,0068$ & 0,0199 & 0,0010 \\
60 & Desember 2010 & $2,78 \%$ & $6,50 \%$ & $-0,0084$ & 0,0377 & 0,0019 \\
\hline
\end{tabular}

